\title{
REVIEW
}

\section{Extracellular purines, purinergic receptors and tumor growth}

\author{
F Di Virgilio and E Adinolfi
}

Virtually, all tumor cells as well as all immune cells express plasma membrane receptors for extracellular nucleosides (adenosine) and nucleotides (ATP, ADP, UTP, UDP and sugar UDP). The tumor microenvironment is characterized by an unusually high concentration of ATP and adenosine. Adenosine is a major determinant of the immunosuppressive tumor milieu. Sequential hydrolysis of extracellular ATP catalyzed by CD39 and CD73 is the main pathway for the generation of adenosine in the tumor interstitium. Extracellular ATP and adenosine mold both host and tumor responses. Depending on the specific receptor activated, extracellular purines mediate immunosuppression or immunostimulation on the host side, and growth stimulation or cytotoxicity on the tumor side. Recent progress in this field is providing the key to decode this complex scenario and to lay the basis to harness the potential benefits for therapy. Preclinical data show that targeting the adenosine-generating pathway (that is, CD73) or adenosinergic receptors (that is, A2A) relieves immunosuppresion and potently inhibits tumor growth. On the other hand, growth of experimental tumors is strongly inhibited by targeting the P2X7 ATP-selective receptor of cancer and immune cells. This review summarizes the recent data on the role played by extracellular purines (purinergic signaling) in host-tumor interaction and highlights novel therapeutic options stemming from recent advances in this field.

Oncogene (2017) 36, 293-303; doi:10.1038/onc.2016.206; published online 20 June 2016

\section{INTRODUCTION}

Purines and pyrimidines, basic elements of all living organisms, are the scaffold constituents of nucleosides and nucleotides, ubiquitous molecules that perform a multiplicity of functions as building blocks of nucleic acids, coenzymes, allosteric modulators, energy intermediates, intracellular and extracellular messengers. Although the initial data suggesting a signaling role for extracellular nucleotides co-dated with the first isolation of ATP from muscle, ${ }^{1,2}$ nucleosides (adenosine) and nucleotides (ADP, ATP, UDP and UTP) were recognized as bona fide extracellular messengers only very recently, thanks to intuition and pioneering work of Geoff Burnstock, now supported by a wealth of experimental findings in nearly every biological system., Without doubt, the definitive sanction of the purinergic hypothesis was provided by cloning, initially of $\mathrm{P} 2 \mathrm{Y}^{5}$ and $\mathrm{P} 2 \mathrm{X} 1^{6,7}$ swiftly followed by all the other members of the family. Extracellular nucleosides and nucleotides participate in a wealth of different cellular responses, among which stimulation (or inhibition) of cell death, proliferation, migration, differentiation, secretion of growth factors and inflammatory mediators. ${ }^{8-11}$ Fundamental pathophysiological processes such as tissue homeostasis, wound healing, neurodegeneration, immunity, inflammation and cancer are modulated by purinergic signaling.

Despite the solid evidence of an extracellular messenger role for pyrimidine nucleotides (UDP and UTP) in epithelia, hematopoietic cells, immune cells and neurons, ${ }^{12-15}$ purinergic signaling in cancer mainly focuses on adenine nucleosides (adenosine) and nucleotides (ADP and ATP). This bias might be due to an excessively conservative approach by the specialist community, but might also simply reflect the much wider spectrum of activity of ATP versus UTP or UDP. In fact, while pyrimidine nucleotides,
UTP, UDP and UDP-glucose are agonists only at four $P 2 Y$ receptor (P2YR) subtypes (P2Y2R, P2Y4R, P2Y6R and P2Y14R), ${ }^{14}$ and at none of the $P 2 X$ receptors ( $P 2 X R$ ) subtypes, ATP activates all P2Rs, with the possible exception of $P 2 Y 12 R$ where the preferred/selective agonist is ADP. ${ }^{16}$ In addition, the adenosine/ATP-based cellular communication system has now been satisfactorily dissected in almost all its components, that is, sources and concentrations of the agonists, plasma membrane receptors, and pathways of degradation. Mechanism of ATP release is as yet incompletely characterized, despite the many pathways (connexins, pannexins, $A B C$ transporters and secretory granules) identified in different cell types. ${ }^{17}$ The extracellular pyrimidine nucleotide system is also poorly known, being not even clear whether inosine has any relevant extracellular biological function. Inosine is reported to be a weak agonist at rodent adenosine $A 3$ receptor (A3R), but it might also indirectly affect purinergic signaling by competing with nucleoside transport. ${ }^{18}$ Moreover, compared with the more widespread and reliable luciferase-based techniques available for ATP measurement, measurement of uridine nucleotides and nucleosides in the extracellular space is still a rather cumbersome procedure, despite the recent generation of a UTPspecific ELISA kit.

ATP fulfills all the requirements for a true extracellular messenger: (a) it is present in very minute amounts ( $\mathrm{nmol} / \mathrm{l}$ ) in the extracellular space under physiological conditions (for example, resting cells or healthy tissues); (b) it is stored intracellularly to very high amounts (from 5 to $10 \mathrm{mmol} / \mathrm{l}$ ); (c) it is water soluble; and (d) it is quickly degraded by ubiquitous extracellular nucleotidases. These features allow the rapid generation of a perfect extracellular messenger molecule characterized by: (a) high signal-to-noise ratio (thanks to the large

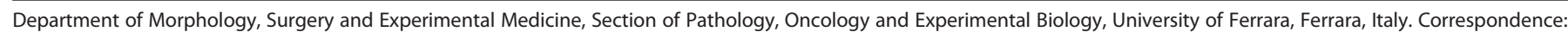

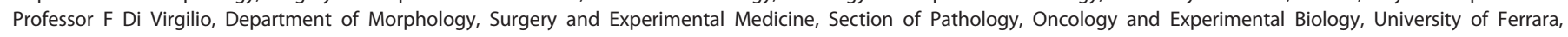
Via Borsari 46, Ferrara 44121, Italy.

E-mail: fdv@unife.it

Received 31 March 2016; revised 2 May 2016; accepted 2 May 2016; published online 20 June 2016 
trans-plasma membrane gradient, release of even minute amounts of cellular ATP will cause a large fractional increase of the extracellular ATP concentration); (b) rapid diffusion through the aqueous tissue interstitium; and (c) rapid termination of the signal to avoid overstimulation or receptor desensitization.

The biochemistry of extracellular adenosine is different as it is now clear that, despite the presence of equilibrative plasma membrane transporters, ${ }^{19}$ the intracellular adenosine pool is not a major source of extracellular adenosine, which is mostly generated via ATP/ADP/AMP hydrolysis by plasma membrane nucleotidases. ${ }^{20,21}$ Therefore, adenosine is produced 'in situ' from extracellular nucleotides, suggesting that ATP/ADP/AMP accumulation in the tissue interstitium will unavoidably end up with an accumulation of adenosine. Extracellular adenosine acts at specific plasma membrane receptors, namely, $\mathrm{P} 1$ receptors (P1Rs) and it is degraded to inosine by adenosine deaminase. Inosine is finally degraded to hypoxantine by purine nucleoside phosphorylase. Adenosine can also be taken up by cells and phosphorylated to cyclic AMP by adenosine kinase. In contrast to ATP, adenosine is highly lipophilic; therefore, it is thought to be active in close proximity to the site of generation, very likely in a restricted microenvironment at the surface of the plasma membrane.

\section{ATP AND ADENOSINE ARE MAJOR CONSTITUENTS OF THE TUMOR MICROENVIRONMENT}

It might seem paradoxical, but the in vivo demonstration that the extracellular ATP concentration changes in pathophysiological conditions, a basic tenet of the purinergic hypothesis, has been satisfactorily answered only in recent years, well after most of the other aspects of the purinergic signaling system had been extensively clarified. It is worth mentioning that for many years, it was even doubted that ATP, and its metabolites, were present in the extracellular space to any significant extent. This bias persisted even after nucleoside and nucleotide receptors were cloned and $\kappa_{\mathrm{d}}$ for adenosine and ATP were measured, revealing an affinity in the low micromolar range, compatible with the activation by relatively low nucleotide concentrations (with the exception of the P2X7 receptor, P2X7R). However, some caution should be exercised as $\kappa_{d}$ measured in vitro or in non-strictly physiological conditions might not reflect the actual affinities, which might be modified by poorly characterized in vivo conditions, such as the presence of naturally occurring allosteric modulators or local tissue changes in $\mathrm{pH}$ and ion concentration.

In recent years, the difficult challenge of measuring the extracellular ATP concentration in intact tissues has been tackled in different ways, and all techniques used provided the same answer: ATP level in the interstitium of resting/healthy tissues is very low, in the nanomolar range, whereas in stimulated or diseased tissues it can reach hundreds of $\mu \mathrm{mol} / \mathrm{I}^{22,23}$ As ATP is rapidly degraded in biological fluids, it is generally understood that physiologically relevant ATP concentrations only build up in the proximity of the plasma membrane. To measure ATP in the pericellular space, Dubyak and co-workers used a luciferase fused in frame with the IgG-binding domain of protein A from Staphylococcus aureus, which was then bound to IgG absorbed onto the cell surface. ${ }^{24}$ Other more sophisticated techniques based on atomic force microscopy, ${ }^{25}$ patch-clamp ${ }^{26}$ or tandem enzyme reactions ${ }^{27}$ have also been proposed, but these techniques, maybe because of their inherent complexity, did not enjoy widespread acceptance. Microelectrode recording has also been applied to extracellular ATP measurement in tissue slices and in vivo. ${ }^{28}$ Although expensive, this technique is straightforward and dependable, but suffers of an intrinsic limit: the mere insertion of the electrode tip into the tissue causes itself tissue damage and ATP release, a drawback that might upset a faithful determination of physiological extracellular ATP levels under unperturbed conditions.
So far, the probe that provides most reliable measurements of the interstitial ATP concentration is the chimeric luciferase (named, pmeLUC, that is, plasma membrane luciferase) engineered in our laboratory. 22,29 This probe was designed to allow ATP measurement close to the cell surface, or at sites of close cell-to-cell contact. The pmeLUC probe is very versatile, can be transfected into most cell types and makes it possible to generate reporter cells of widely different lineage (for example, mesenchymal cells, immune cells and tumor cells) apt to sense the ATP concentration in a multiplicity of in vivo settings. ${ }^{30-34}$ Cells engineered with pmeLUC can be directly inoculated into solid tumors or intraperitoneally to monitor ATP levels at metastatic sites. Use of the pmeLUC probe has unequivocally demonstrated that in healthy tissues the extracellular ATP level is very low (few $\mathrm{nmol} / \mathrm{l})$, whereas at sites of tissue damage, inflammation and more importantly in the tumor microenvironment (TME) or at site of metastases, extracellular ATP can be as high as a few hundred $\mu \mathrm{mol} / \mathrm{l}$. PmeLUC luminescence can be easily in vivo recorded by total body luminometry, thus allowing continuous monitoring of changes in the ATP concentration in the TME, and in principle even within pre-metastatic niches (Figure 1). ${ }^{35}$ It is worth mentioning that pmeLUC might report ATP levels in microdomains close to the plasma membrane, or at sites of close contact between adjacent cells, where the concentration of this nucleotide might substantially exceed that of the interstitial fluid away from the cell surface.

Adenosine is also reported to be elevated in the $\mathrm{TME}^{36}$ a finding not surprising in view of the high extracellular ATP level. Direct in vivo measurements of the adenosine concentration in tumors are not as yet available, but ex vivo data clearly report an adenosine concentration at least 30\% higher in the tumor core than in the periphery, and overall at least twice higher in tumors than in healthy tissues. ${ }^{36}$ These data are in keeping with previous observations showing that adenosine concentration in the effluent blood from lung and colon adenocarcinomas was
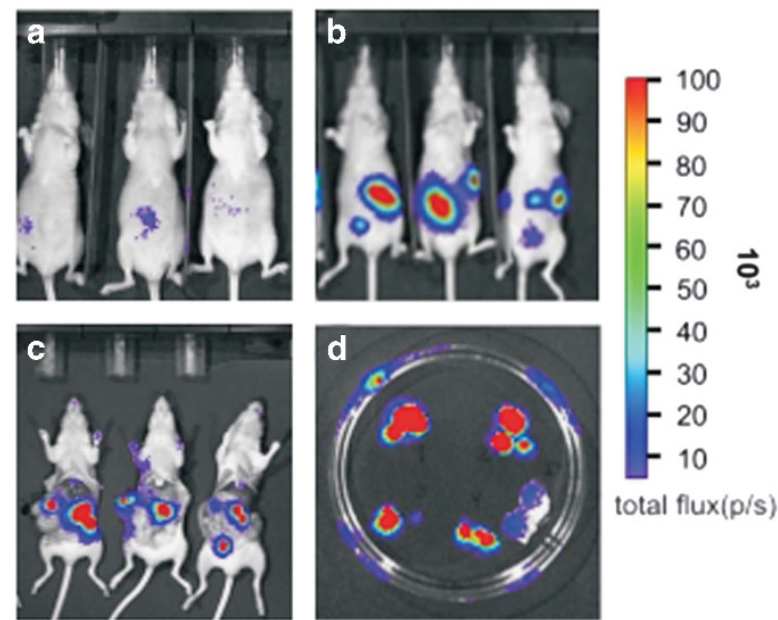

Figure 1. Increased extracellular ATP concentration at tumor sites. Healthy (a) or human ovarian carcinoma (OVCAR)-bearing (b and $\mathbf{c}$ ) nude/nude mice were intraperitoneally (i.p.) injected with $2 \times 10^{6}$ HEK293-pmeLUC cells and monitored for luminescence emission. Luminescence was measured starting at day 2 after pmeLUC cell inoculation, and every 2 days thereafter for a total of 16 days. No luminescence was detected from healthy mice (a), except for a minor emission likely due to tissue damage following i.p. injection. On the contrary, strong light emission was detected from tumor-bearing mice (b). Luminescence was localized at discrete sites that, at post-mortem analysis, coincided with metastases on the visceral abdominal wall (c). Excised metastases were also strongly luminescent (d). Modified from Pellegatti et al. ${ }^{35}$ 
significantly higher (from 0.2 to $2.4 \mu \mathrm{mol} / \mathrm{l}$ ) than in the effluent from healthy tissues (about $30 \mathrm{nmol} / \mathrm{l}$ ). ${ }^{37}$ Adenosine levels in the effluent were further increased by the addition of inhibitors of adenosine metabolism. Compelling evidence demonstrates that the bulk of extracellular adenosine is generated at the expenses of extracellular ATP via the sequential activity of CD39 and CD73 ectonucleotidases. ${ }^{38,39}$ CD39 is a member of the ectonucleoside triphosphate diphosphohydrolase (E-NTPDase) family that is comprised of four members: E-NTPDase1 (CD39), E-NTPDase2, E-NTPDase3 and E-NTPDase4. ${ }^{20}$ These are plasma membrane-bound enzymes that degrade with different affinities ATP and ADP to AMP. AMP in turn is degraded to adenosine by $5^{\prime}$ ectonucleotidase CD73, which is the only member of the $5^{\prime}$ ectonucleotidase enzyme family expressed on the outer surface of the plasma membrane. The tandem activity of CD39 and CD73 is the most important pathway for the generation of extracellular adenosine in healthy or neoplastic tissues. Increased expression of these enzymes has been reported in several tumors. ${ }^{40-42}$ Adenosine can also be generated by the CD38 pathway via ADP-ribose generation from extracellular NAD, and further degradation of ADP-ribose to AMP by the enzyme ectonucleoside pyrophosphatase/phosphodiesterase. ${ }^{21}$ AMP degradation via CD73 is the final common pathway for all major extracellular adenosine-generating systems.

\section{CELLULAR TARGETS OF ATP AND ADENOSINE}

Virtually, all cell types express purinergic receptors of the $\mathrm{P} 2$ and $\mathrm{P} 1$ subtype. The P2R family is further subdivided into the P2Y (eight members, P2Y1, P2Y2, P2Y4, P2Y6 and P2Y11-P2Y14) and P2X (seven members, P2X1-7) subfamilies. P2YRs are coupled via G-proteins (Gq/11, Gs or Gi/o) to $\mathrm{Ca}^{2+}$ mobilization and cyclic AMP generation/inhibition, as well as to stimulation of the ERK/MAPK pathway. ${ }^{43}$ P2XRs are homo/heterotrimeric ion channels that mediate transmembrane fluxes of mono- $\left(\mathrm{Na}^{+}\right.$and $\left.\mathrm{K}^{+}\right)$and divalent $\left(\mathrm{Ca}^{2+}\right)$ ions ${ }^{44}$ (Table 1). Upon sustained stimulation with ATP, the P2X7R channel undergoes a large increase in conductance and a shift in selectivity, from cation-selective to nonselective. $^{45,46}$ Under these conditions, the plasma membrane becomes permeable to aqueous solutes of molecular weight (MW) up to $900 \mathrm{Da}{ }^{44}$ Despite reports claiming that other P2XR subtypes (for example, P2X2 and P2X4) trigger a similar increase in the plasma membrane permeability to large hydrophylic

\begin{tabular}{|c|c|c|}
\hline $\begin{array}{l}\text { P2R } \\
\text { subtype }\end{array}$ & $\begin{array}{l}\text { Preferred } \\
\text { natural } \\
\text { ligand }\end{array}$ & Signal transduction mechanism \\
\hline P2X1 & ATP & $\mathrm{Na}^{+}, \mathrm{K}^{+}$and $\mathrm{Ca}^{2+}$-selective ion channel \\
\hline $\mathrm{P} 2 \mathrm{X} 2$ & ATP & $\mathrm{Na}^{+}, \mathrm{K}^{+}$and $\mathrm{Ca}^{2+}$-selective ion channel \\
\hline $\mathrm{P} 2 \mathrm{X} 3$ & ATP & $\mathrm{Na}^{+}, \mathrm{K}^{+}$and $\mathrm{Ca}^{2+}$-selective ion channel \\
\hline P2X4 & ATP & $\mathrm{Na}^{+}, \mathrm{K}^{+}$and $\mathrm{Ca}^{2+}$-selective ion channel \\
\hline P2X5 & ATP & $\mathrm{Na}^{+}, \mathrm{K}^{+}$and $\mathrm{Ca}^{2+}$-selective ion channel \\
\hline P2X6 & ATP & $\mathrm{Na}^{+}, \mathrm{K}^{+}$and $\mathrm{Ca}^{2+}$-selective ion channel \\
\hline $\mathrm{P} 2 \mathrm{X} 7$ & ATP & $\begin{array}{l}\mathrm{Na}^{+}, \mathrm{K}^{+} \text {and } \mathrm{Ca}^{2+} \text {-selective ion channel and } \\
\text { large pore permeable to solutes up to } 900 \mathrm{Da}\end{array}$ \\
\hline $\mathrm{P} 2 \mathrm{Y} 1$ & ADP & $\mathrm{G}_{\mathrm{q} / 11}\left(\mathrm{IP}_{3} / \mathrm{DAG}\right.$ increase $)$ \\
\hline $\mathrm{P} 2 \mathrm{Y} 2$ & UTP and ATP & $\mathrm{G}_{\mathrm{q} / 11}\left(\mathrm{IP}_{3} / \mathrm{DAG}\right.$ increase $)$ \\
\hline $\mathrm{P} 2 \mathrm{Y} 4$ & UTP & $\begin{array}{l}\mathrm{G}_{\mathrm{q} / 11}\left(\mathrm{IP}_{3} / \mathrm{DAG} \text { increase) and }\right. \\
\mathrm{G}_{\mathrm{i}} \text { (inhibition of cAMP synthesis) }\end{array}$ \\
\hline P2Y6 & UDP & $\mathrm{G}_{\mathrm{q} / 11}\left(\mathrm{IP}_{3} / \mathrm{DAG}\right.$ increase $)$ \\
\hline $\mathrm{P} 2 \mathrm{Y} 11$ & ATP & $\mathrm{G}_{\mathrm{q} / 11}\left(\mathrm{IP}_{3} / \mathrm{DAG}\right.$ increase), $\mathrm{G}_{\mathrm{s}}$ (cAMP increase) \\
\hline $\mathrm{P} 2 \mathrm{Y} 12$ & ADP & $\mathrm{G}_{\mathrm{i}}$ (inhibition of cAMP synthesis) \\
\hline $\mathrm{P} 2 \mathrm{Y} 13$ & ADP & $\mathrm{G}_{\mathrm{i}}$ (inhibition of cAMP synthesis) \\
\hline P2Y14 & UDP-glucose & $\mathrm{G}_{\mathrm{i}}$ (inhibition of cAMP synthesis) \\
\hline
\end{tabular}

molecules, ${ }^{47,48}$ unequivocal demonstration for the opening of such a peculiar pore is available only for the P2X7R subtype, where extensive studies have documented non-lytic uptake of various low-MW hydrophilic fluorescent markers. ${ }^{49-51}$ In other P2XR subtypes, the 'channel-to-pore' transition was almost exclusively documented by electrophysiology techniques, whose adequacy to demonstrate this large-conductance shift has been recently questioned. ${ }^{52}$ An exception might be the P2RX2R/P2RX5R heteromer, which shows the P2X7R-like activity, ethidium bromide and YO-PRO uptake included. ${ }^{53}$ The molecular mechanism of P2X7R-dependent permeabilization of the plasma membrane to large-MW aqueous solutes has long been a matter of controversy. Most credited hypothesis hold that the large-conductance pore results from either (1) dilation of the cation channel ${ }^{54,55}$ or (2) recruitment of an accessory molecule. ${ }^{56}$ Data from pannexin-1 KO mice, however, indicate that pannexin-1 is not an absolute requirement for large-conductance pore formation (Cavagna and Di Virgilio, unpublished), thus suggesting that either recruitment of another plasma membrane molecule occurs or that it is the cation channel itself that dilates to generate the non-selective pore. A response that might explain these P2X7R feature is the marked 'facilitation' (increased activity and enhanced sensitivity with prolonged or repeated exposition to agonist) typical of this receptor. ${ }^{57}$ Furthermore, positive allosteric modulators might also have a role in 'facilitating' the formation of the P2X7R-associated pore. Several years ago, we showed that the antibiotic polymixin $B$ strongly increases all P2X7R-dependent responses, ethidium bromide uptake and cytotoxicity included. ${ }^{58}$ Interestingly, in HEK293 cells transfected with the human P2X7R and treated with polymixin B, the anti-P2X7 Ab stains a 440-kDa band, in addition to the $72-$ and $240-\mathrm{kDa}$ bands, suggesting the presence of a hexameric complex besides the single subunit $(72 \mathrm{kDa})$ and the trimer $(240 \mathrm{kDa})$. Facilitation and positive allosterism might explain the increased activity of the P2X7R at tumor sites.

Adenosine receptors (P1Rs) are comprised of four subtypes, $A 1 R, A 2 A R, A 2 B R$ and A3R. ${ }^{59}$ All P1Rs are G-protein-coupled, linked to $\mathrm{Ca}^{2+}$ mobilization from stores and/or cyclic AMP increase. It is customary to study responses of individual receptor subtypes (that is, P2R and P1R), assuming that they do not interact with each other. However, there is solid evidence that adenosine receptors can form omo- or hetero-oligomers with other receptors (for example, dopamine D1), generating hybrid complexes with a specific pharmacological profile. ${ }^{60,61}$ Whether this might have implications for organ physiology and cancer is not known.

P2Rs and P1Rs are constituents of a signal transduction chain that in vivo operates in tandem as adenosine, the only known physiological agonist at P1Rs, is generated from extracellular ATP (Figure 2). This has relevant implications for the study of nucleotide- or nucleoside-mediated responses, because in principle extracellular ATP and adenosine concentrations, and therefore P2Rs and P1Rs activation, could be changed simply by modulating the ectonucleotidase activity. CD39 deletion/inhibition increases the local ATP/ADP concentration, thus triggering activation of P2Rs, especially of those with low $\kappa_{\mathrm{d}}$. CD73 deletion/inhibition increases local AMP levels and, more importantly, reduces the adenosine concentration, thus inhibiting P1R activation. ${ }^{62}$ On the contrary, CD73 overexpression, or adenosine deaminase blockade, increases the local adenosine concentration.

\section{ADENOSINE RECEPTORS IN CANCER}

Adenosine has been a focus of interest in cancer studies for several years, thus its role is better understood than that of ATP. ${ }^{36-38,63-65}$ Adenosine is one of the most pleiotropic biochemical constituents of the TME affecting both host and tumor responses. On the host side, adenosine is well known for its strong immunodepressive/anti-inflammatory activity. ${ }^{66-68}$ Less clear is its effect on the tumor itself, as depending on the specific adenosine 


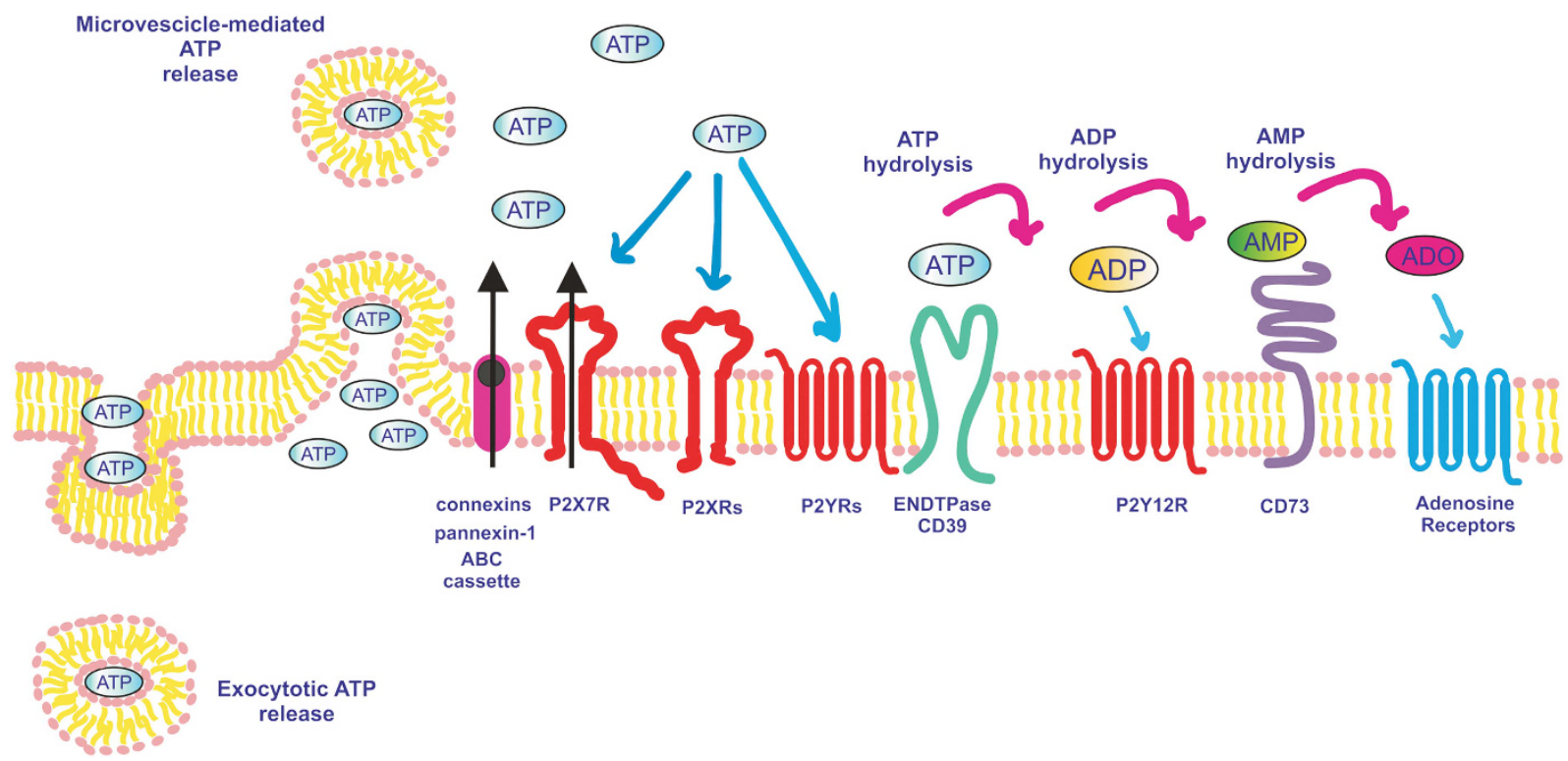

Figure 2. ATP release pathways, receptors and degrading enzymes involved in purinergic signaling. ATP is released into the extracellular space via secretory vesicles (exocytosis), plasma membrane-derived microvesicles, transporters (for example, ABC cassettes), channels (for example, pannexin-1 or connexins) or through the P2X7R itself. Once in the extracellular milieu, ATP acts at P2X and P2Y receptors, and is also hydrolyzed to ADP and AMP by ENTPDases such as CD39. ADP activates P2YR12 and is further degraded to adenosine (ADO) by CD73. CD73-generated adenosine activates adenosine receptors (P1) and is degraded to inosine by adenosine deaminase.

receptors expressed by the tumor cells, both growth stimulation and inhibition have been described. ${ }^{59}$ Likewise both detrimental and beneficial effects stemming from A1R activation have been reported. A1Rs may support breast cancer cell growth and melanoma cell chemotaxis, ${ }^{59,69,70}$ but on the other hand, A1R is expressed at low levels in advanced-stage prostate cancer. ${ }^{71}$ Very recently, the $A 1 R$ was shown to have a protective activity in endometrial carcinoma by promoting cortical actin polymerization, increasing cell-cell adhesion and finally helping preserve epithelial integrity. ${ }^{72}$ These responses reduce tissue invasion and metastasis, and will be eventually beneficial. A similar picture is emerging for the A2AR and the A2BR. Stimulation of tumor cell A2ARs may enhance proliferation, for example, in MCF-7 breast cancer, ${ }^{73}$ or trigger cell death, for example, in A375 melanoma cells. ${ }^{74}$ Direct effects of tumor A2BR stimulation are less known. The few data available suggest that in MDA-MB-231 cells, A2BR activation inhibits proliferation via the ERK pathway. ${ }^{59}$ In oral squamous cell carcinoma, the $A 2 B R$ is overexpressed and its silencing inhibits growth. ${ }^{75}$ A2BR might also have an important role in supporting invasion and metastatic spreading. A recent work shows that $\mathrm{A} 2 \mathrm{BR}$ activation causes the accumulation of nonprenylated Rap 1B, a small GTPase controlling cell adhesion. ${ }^{76}$ This enhances cell scattering and might promote cancer cell invasion. Blockade of A2BR slows growth of bladder and breast tumors injected into the syngeneic mice, probably by enhancing T-cell-mediated anti-tumor response. ${ }^{77}$ The role the A3Rs in cancer has been more thoroughly investigated, yet also for this receptor, contrasting results are reported. A3Rs are expressed by many different human tumor cell lines (for example, K562 erythroleukemia, Jurkat lymphoma and A375 human melanoma), and by several primary human tumors (glioblastoma and prostatic cancer), where there is hint that its expression might correlate with disease progression. ${ }^{59,78} \mathrm{~A} 3 \mathrm{R}$ stimulation inhibits proliferation of PC3 prostate carcinoma, HCT-116 colon carcinoma and MIA$\mathrm{PaCa}$ pancreatic carcinoma, but on the other hand promotes proliferation of $\mathrm{HT} 29$ and $\mathrm{CaCO} 2$ colon cancer cells. ${ }^{59}$ The A3R couples with the glycogen synthase kinase (GSK)-3 $\beta$ WNT/ $\beta$ catenin pathway; therefore, it was suggested to inhibit proliferation via this pathway. ${ }^{79}$ Contrasting data are reported on the effect of A3R stimulation on metastatic spreading. ${ }^{80,81}$ Despite these conflicting results, the $A 3 R$ is the adenosine receptor most widely distributed and more amenable for pharmacological targeting in cancer cells. ${ }^{82,83} \mathrm{~A}$ phase $\mathrm{I} / \mathrm{II}$ clinical trial to test the efficacy of A3R agonists for the treatment of hepatocellular carcinoma has been completed, retrieving encouraging results ${ }^{84}$ and two more are about to start (https://clinicaltrials.gov/).

\section{ATP RECEPTORS IN CANCER}

Virtually, all tumor cell lines and many primary human tumors so far investigated express P2Rs and are sensitive to ATP. ${ }^{85}$ P2Y1R and P2Y2R support growth, thus it is reasonable to hypothesize that the increased ATP content of the TME might drive cancer cell proliferation via these receptors. ${ }^{86}$ In addition, P2YRs might also support invasiveness and metastatic spreading by promoting migration or chemotaxis, as shown in breast or prostate cancer, ${ }^{87-89}$ or might contribute to formation of the metastatic niche in breast cancer. ${ }^{90}$ However, the opposite outcome of P2Y1R or P2Y2R activation has also been described, that is, inhibition of proliferation of nasopharyngeal carcinoma ${ }^{91}$ or outright apoptosis of human colon carcinoma cells. ${ }^{92}$ More recently, a crucial role for the P2Y2R in metastatic spreading has been highlighted. It is well known that cancer cells are transported in the blood as plateletcovered tumor emboli, and that platelet activation facilitates tumor cell extravasation and metastases formation. ${ }^{93,94}$ It has now been shown that tumor emboli trigger nucleotide (ADP and ATP) release from platelets; nucleotides in turn activate endothelial cell P2Y2R to promote transendothelial migration of the tumor cells. ${ }^{95}$ Accordingly, mice genetically deleted of P2Y2R or harboring platelets defective in ATP secretion undergo reduced metastatic dissemination. To further strengthen the role of the P2YRs in cancer, P2Y2, P2Y1 and P2Y6 were recently identified among those genes whose activation is responsible for driving resistance to ALK inhibitors in the lung. ${ }^{96}$

Tumor cell killing by $\mathrm{mmol} / \mathrm{l}$ ATP concentrations is a longstanding observation. ${ }^{85,97}$ In most cases, this effect is mediated by the P2X7R, a receptor widely expressed by cancer cells. However, against this marked outcome due to P2X7R overstimulation, it is 
now clear that tonic, low level, P2X7R stimulation often promotes cell survival and proliferation. ${ }^{97}$ Thus, the P2X7R behaves as a bi-functional receptor that, depending on the level of activation and the cell type, triggers cell death or alternatively supports growth. ${ }^{50,98-101}$ Although P2X7R overstimulation precipitates a marked mitochondrial catastrophe, tonic stimulation stabilizes the mitochondrial network, increases mitochondrial potential and enhances the efficiency of oxidative phosphorylation. ${ }^{102}$ Quite surprisingly, at the same time, P2X7R activation increases lactic acid output and upmodulates almost all enzyme and transporters involved in glycolysis and shown to participate in the 'Warburg effect', that is, Glut-1, glyceraldehyde 3-phosphate dehydrogenase, phosphofructokinase, pyruvate kinase $M 2$ and pyruvate dehydrogenase kinase 1 . In addition, P2X7R stimulation inactivates GSK-3 $\beta$, thus expanding intracellular glycogen stores. ${ }^{103,104}$ The combined potentiation of oxidative phosphorylation as well as of aerobic glycolysis results in a large increase in the overall intracellular ATP content. ${ }^{102} \mathrm{~A}$ sustained aerobic glycolysis is also necessary to generate abundant biosynthetic intermediates for the synthesis of nucleic acids, phospholipids and non-essential aminoacids (anaplerotic reaction), and to accumulate reducing equivalents in the form of NADPH. The stimulation by P2X7R of both energy metabolism and anaplerosis results in a striking proliferative advantage of P2X7R-expressing cells. ${ }^{102,104-116}$ The central role of $\mathrm{P} 2 \mathrm{X} 7 \mathrm{R}$ in cell growth is witnessed by the strong growth inhibitory effect of P2X7R blockers or silencing. ${ }^{104,109,117}$

Despite dissection of the growth-promoting signal transduction cascade downhill to P2X7R is still rather preliminary, convergent data indicate that PI3K/Akt and ERK kinases, and HIF-1a and NFATC1 transcription factors have a central role. ${ }^{103,104,118-120}$ The PI3K/Akt pathway is involved in P2X7R-dependent tumor cell growth, invasiveness, metastatic spreading and angiogenesis. ${ }^{104,121}$ In addition, this pathway seems to activate a positive-feedback (amplification) mechanism, as P2X7R expression is in turn up modulated by PI3K/Akt via SP1. ${ }^{113}$

There is a hint that the P2X7R might also contribute to cancer cell invasiveness and metastatic spreading, as its expression enhances infiltration in soft agar and release of active cysteine cathepsins, enzymes overexpressed by cancer cells and known to digest the extracellular matrix. ${ }^{122,123}$ P2X7R stimulation supports migration of PC9 lung carcinoma and T47D breast cancer cells, ${ }^{124,125}$ whereas its silencing inhibits prostate cancer cell migration and invasiveness in vitro and in vivo. In addition, P2X7R silencing attenuated expression of genes involved in epithelial/ mesenchymal transition such as Snail, E-cadherin, Claudin-1, IL-8 and MMP-3. ${ }^{121}$

The increasing body of evidence implicating P2X7R in cancer is supported by recent studies, suggesting that P2X7R overexpression might be a negative prognostic indicator in malignancies such as, for example, chronic lymphocytic and acute myeloid leukemia, ${ }^{101,126}$ papillary thyroid carcinoma, ${ }^{127}$ prostate cancer ${ }^{128}$ and neuroblastoma ${ }^{104}$ (the reader is referred to recent reviews for an exhaustive list of cancer cell types in which P2X7R expression has been demonstrated). ${ }^{85,114,129}$ Moreover, Solini et al. ${ }^{130}$ recently identified specific genetic profiles of P2X7R and vascular endothelial growth factor (VEGF) receptor 2 (VGFR2) polymorphisms associated with a favorable or unfavorable prognosis in prostate cancer. Although in this study single P2X7R (rs3751143 and rs208294) or VGFR2 (rs2071559 and rs11133360) polymorphisms did not correlate with a significant change in overall survival, their combination identified patient cohorts with a better or worse prognosis. The interaction between P2X7R and VEGFR2 is not completely unexpected, as it has been shown that P2X7R is a potent stimulant of VEGF release in vitro and in vivo. ${ }^{109,131}$ Accordingly, in vivo studies show that VEGF blockade by bevacizumab strongly inhibits growth of P2X7R-expressing tumors. $^{109}$ Relationship of P2X7R with the VEGF pathway is very intriguing, as this receptor has also been shown to directly modulate expression of VEGFR2. ${ }^{132}$ Although P2X7R is the receptor more intensively investigated in cancer in the $P 2 X R$ family, P2X3R and P2X5R have also been implicated in oncogenesis.

P2X3R overexpression has been shown to promote proliferation via the JNK pathway in hepatocellular carcinoma and to be associated with an unfavorable prognosis. ${ }^{133}$ The role of P2X3R in proliferation is intriguing as this receptor is rapidly desensitizing in the presence of physiological ATP concentrations, thus it seems that either in tumor cells its desensitization is defective or the TME contains factors that prevent its desensitization. The P2X5R is heavily expressed in human basal cell and squamous carcinomas, and is associated with differentiation, suggesting that its activation might indeed counteract cancer cell growth. ${ }^{134}$ Different human P2X5R splice variants are present, the most common of which is missing exon 10 or both exons 3 and 10, and is therefore unable to form a functional ion channel. ${ }^{135,136}$ Recently, this defective human P2X5R splice variant has been shown to be a minor histocompatibility antigen specifically expressed on lymphoid and myeloid leukemia cells, and has been suggested to be a suitable target for immunotherapy. ${ }^{126,137-139}$

\section{NUCLEOTIDE-METABOLIZING ENZYMES IN CANCER}

The conversion of ATP to adenosine is a crucial feature of purinergic signaling in physiological as well as pathological conditions. The two main ectonucleotidases involved, CD39 and CD73, are key modulators of the biochemical composition of the TME. $^{62}$ It is currently understood that the main mechanism by which CD39 and CD73 affect tumor growth depends on their ability to produce adenosine, and thus promote an immunosuppressive TME. However, the function of adenosine in the TME is not always straightforward as there is now evidence that in endometrial cancer adenosine might have direct anti-tumor effects as shown by the finding that CD73 deletion in this tumor accelerates progression. ${ }^{72}$ This beneficial effect of adenosine is mediated via A1R and seems to be due to its ability to promote epithelial integrity and thus restrain invasiveness. Other studies suggest that CD73 expression has quite opposite outcomes on tumor growth depending on whether it is expressed on the host or on the tumor cells. In fact, although CD73 expression on healthy prostate epithelial cells inhibits immunosurveillance by T cells, and thus promotes prostate cancer growth, expression of CD73 by the cancer cells themselves restrains tumor growth by inhibiting the NF-KB signaling via adenosine generation and A2BR signaling. ${ }^{140}$

There is clear evidence that the typically hypoxic TME facilitates tumor progression by accelerating selection of more aggressive and metastasis-efficient tumor cell clones, and by dysregulating the anti-tumor immune response. Hypoxia-driven HIF-1a activation stimulates the expression of CD39 and CD73, thus increasing adenosine production. ${ }^{141}$ Deletion of either CD39 or CD73 results in amelioration of anti-tumor immunity and improvement in survival. ${ }^{142,143}$ It appears that the expression of adenosineproducing ectoenzymes is critical in hematopoietic as well as non-hematopoietic tissues, ${ }^{143}$ possibly because CD73 participates in angiogenesis and might increase migration and metastatic dissemination of tumor cells via a mechanism independent of the immune response. A recent large-scale study analyzing over 6000 triple-negative breast cancers showed that CD73 overexpression and overactivation of adenosinergic $A 2 A$ and $A 2 B$ receptors substantially contributed to resistance to chemotherapy. ${ }^{144}$ Direct targeting CD39 or CD73 with small-molecule inhibitors or specific monoclonal antibodies has yielded very promising results. ${ }^{143,145,146}$ In all these studies, therapeutic efficacy required an active immune system, highlighting the beneficial effects of adenosine blockade on the re-activation of anti-tumor immunity.

The adenosinergic pathway is exquisitely sensitive to the intratumor oxygen level. It is well established that hypoxia drives CD39 


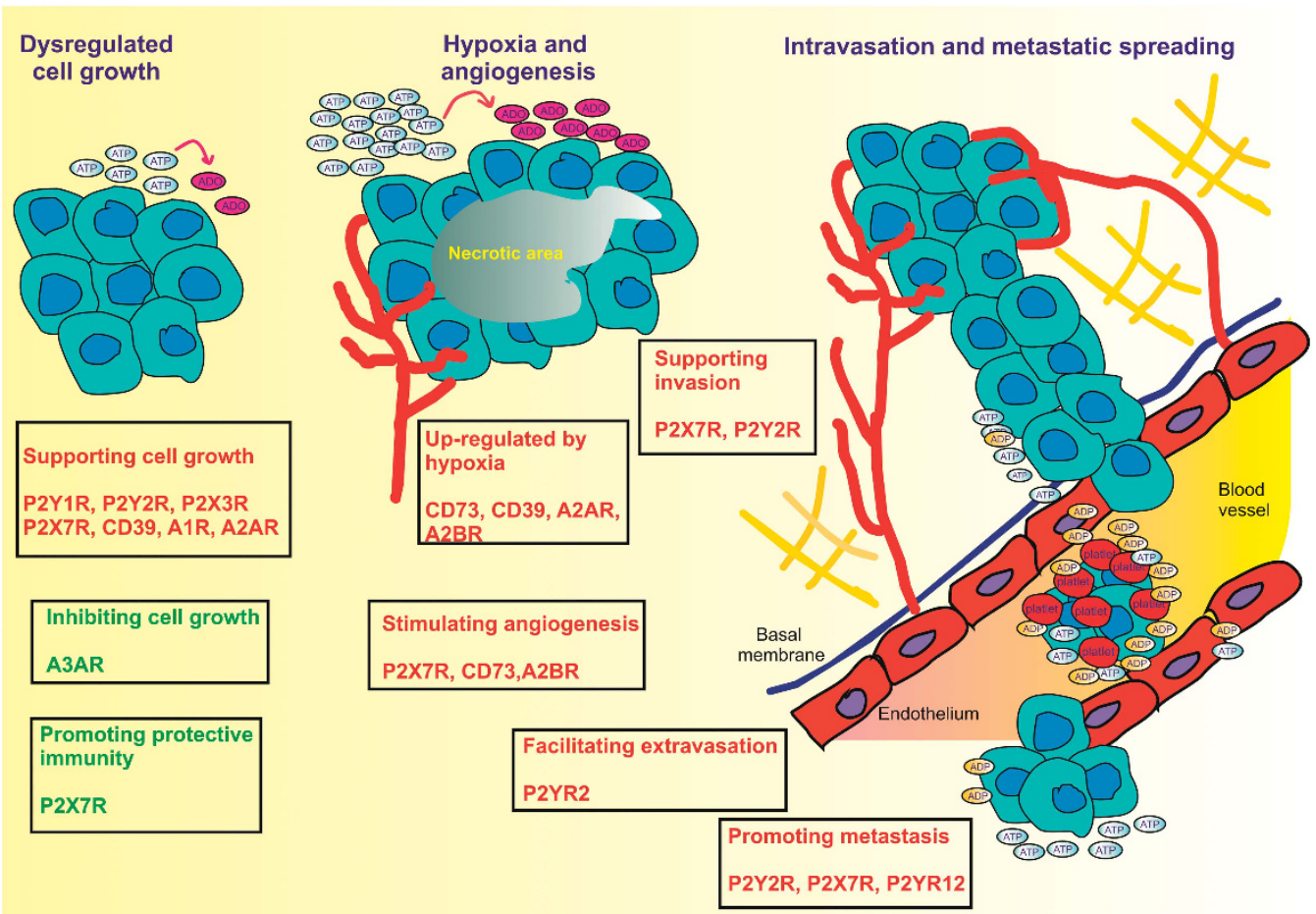

Figure 3. Purinergic signaling modulates multiple steps in tumor progression. Extracellular nucleotides and nucleosides participate in all the main phases of tumor progression with opposite effects (red, supporting tumor growth; green, opposing tumor growth), depending on the specific receptor subtype activated. Hypoxia in the tumor core causes accumulation of ATP and adenosine, and promotes CD73, CD39, A2AR and A2BR expression. In addition, hypoxia also promotes expression of P2X7R and CD73, which in turn stimulate angiogenesis. Nucleotides and their receptors promote extracellular matrix degradation and tissue invasion (P2X7R and P2Y2R), tumor cell migration, extravasation and metastatic dissemination (P2Y2R, P2X7R and P2Y12R).

and CD73 expression via transcription factors Sp1 and HIF-1a, respectively, ${ }^{141,147}$ and therefore promotes adenosine generation. Sitkovsky and co-workers now provide an elegant in vivo proof that by promoting respiratory hyperoxia adenosine signaling is inhibited and tumor growth reduced. ${ }^{148}$ In this study, breathing $60 \%$ oxygen effectively reduced hypoxia and adenosine content of the TME, inhibited MCA205 lung fibrosarcoma growth and strongly reduced the number of B16 melanoma pulmonary metastasis. The protective effect of hyperhypoxia was almost entirely dependent on NK cells, an effect possibly due to the exquisite sensitivity of $\mathrm{NK}$ cells to A2A receptor-mediated inhibition. ${ }^{149}$ Quite interestingly in view of the exciting results from novel therapies based on immune checkpoint targeting, ${ }^{150}$ respiratory hyperoxia reduced CTLA4 expression by tumorinfiltrating regulatory $T$ cells. ${ }^{148}$ A schematic summary of the main pro- or anti-tumorigenic effects mediated by purinergic signaling is shown in Figure 3.

\section{IMPACT OF PURINERGIC SIGNALING ON CANCER THERAPY}

Identification of multiple and at least partially independent targets paves the way for further developments of combinatorial therapies. Current cancer therapeutics, notably chemotherapy and radiotherapy, are based on the direct cytotoxic effects on cancer cells (and unfortunately on the host tissues as well). One of the main consequences of tumor and host cell necrosis is a large release of ATP leading to adenosine accumulation and immunosuppression. In a mouse model of triple-negative breast cancer, combined treatment with doxorubicin and anti-CD73 or A2A receptor antagonists produced a significant increase in survival. ${ }^{144}$ Encouraging results were also obtained by combining targeting the adenosinergic pathway and anti-PD-1 and anti-CTLA4 therapy. ${ }^{151}$ In preclinical models, simultaneous blockade of immune checkpoints and A2A receptors enhanced cytotoxic T lymphocyte and NK cell activity, and reduced metastatic dissemination. ${ }^{152}$

Fundamental components of immunosuppressive TME are myelod-derived suppressor cells (MDSCs). ${ }^{153}$ Purinergic signaling in MDSCs has been a largely neglected issue. ${ }^{154}$ Tumor-associated myeloid cells express high levels of plasma membrane CD39/ CD73, which are upregulated by the transforming growth factor-beta signaling. ${ }^{155}$ Granulocytic MDSCs (G-MDSCs) were reported to express high $C D 73$ levels, ${ }^{156}$ and thus contribute to the immunosuppressive TME. Deletion of A2AR in myeloid cells was shown to revert immunosuppression in B16 melanomabearing mice via potentiation of NK and cytotoxic T lymphocytes responses. ${ }^{157}$ However, as the A2AR was deleted in macrophage, dendritic cells as well as in $\mathrm{Lys} 6 \mathrm{G}^{+}$(granulocytic) and Lys6C (monocytic) cells, this study does not allow appreciating the effect of the specific deletion of MDSC A2AR. Little information is available on the function of other members of the P1R family (A1R, $A 2 B R$ and $A 3 R$ ) in MDSCs. There is evidence that blockade of A2BR receptor inhibits the recruitment of MDSC into the $T M E,{ }^{158}$ but whether this is related to a direct effect on MDSC A2B rather than being an indirect effect of inhibition of release of A2BR-controlled chemoattractants by other immune or stromal cells is not known. The P2X7R is overexpressed in MDSCs, where it triggers expression and/or release of immunosuppressive factors such as IL10, arginase and transforming growth factor-beta, ${ }^{33,159}$ but whether the P2X7R participates in MDSC-dependent immunosuppression is not known. If P2X7R-dependent release of immunosuppressive factors from MDSCs contributes to the inhibition of the anti-tumor immune response, then P2X7R targeting might relieve immunosuppression. A schematic rendition of the multiple effects of extracellular ATP and adenosine on anti-tumor immune response is shown in Figure 4. 

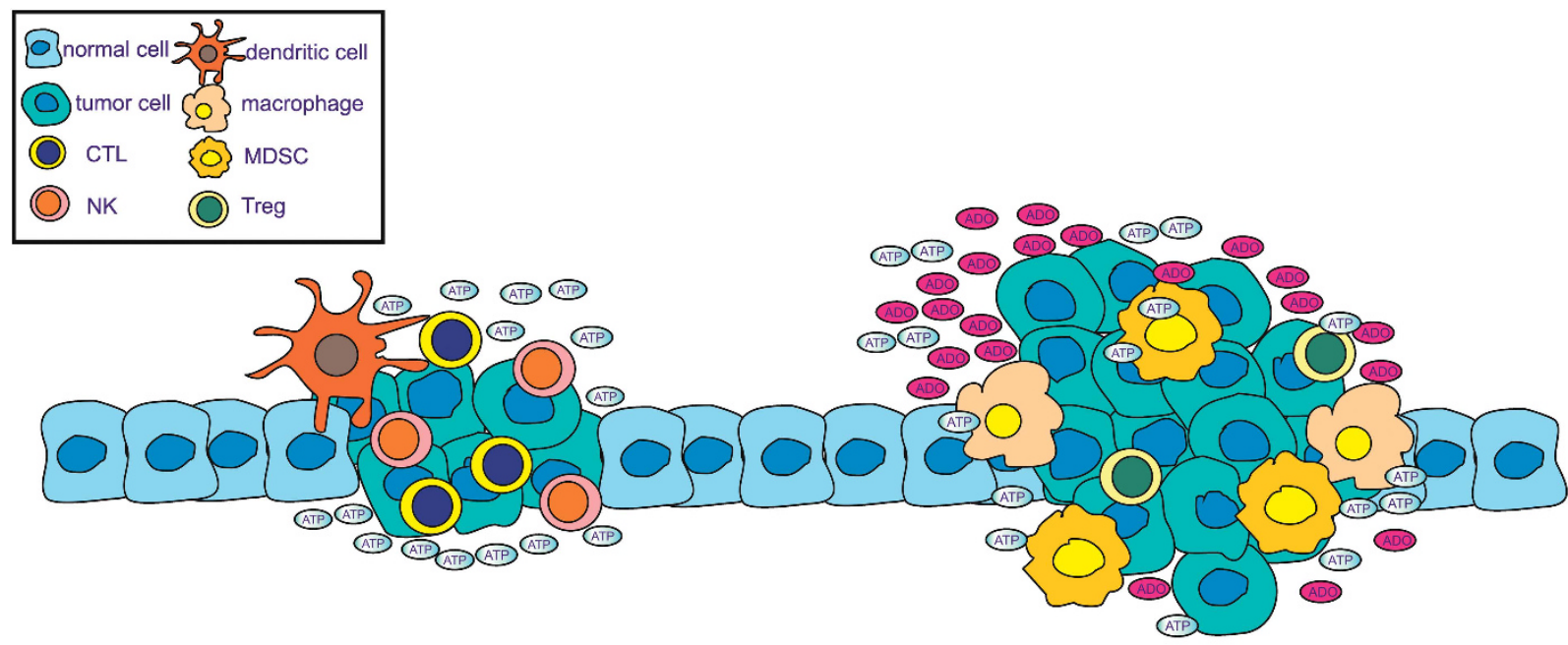

Tumor elimination

Promoted by

P2X7R expressed by dendritic cells

Inhibited by

A2AR expressed on T cells,

macrophages and dendritic cells

\section{Tumor escape}

Promoted by

CD39, CD73 expressed by tumor-infiltrating immune cells A2AR expressed by NK cells P2X7R expressed by MDSC, M2 macrophage and Treg

Figure 4. Role of purinergic receptors in immuno-editing. Purinergic signaling has a crucial role in tumor-host interaction. Cancer cell elimination is facilitated by activation of the P2X7R receptor expressed by dendritic cells, which helps presentation of tumor antigens to T lymphocytes. On the other hand, CD39 and CD73 promote accumulation of adenosine into the tumor microenvironment and activation of immunosuppressive A2AR. The P2X7R may also participate in tumor escape, albeit with an as yet poorly understood role, as it drives release of immunosuppressive factors from MDSCs and supports M2 macrophage and regulatory T-cell responses.

However, high ATP levels in the TME are not always detrimental for the patient, but might also have a beneficial effect by stimulating the anti-tumor host response. It is a long-standing observation that chemotherapeutics such as anthracyclines and oxalilplatin are more effective when administered into immunocompetent rather than to immunodeficient or lymphopenic patients, because these drugs are able to trigger a specific type of cell death, immunogenic cell death, that activates a complex adaptive stress response and potentiates the anti-tumor host immune response. ${ }^{10-162}$ Immunogenic cell death is characterized by surface exposure and release of several immunostimulants (calreticulin, high mobility group box 1 protein (HMGB1), IFNY and ATP), which increase immune cell recruitment, dendritic cell maturation and antigen presentation. ${ }^{163,164}$ Cancer cells killed in vitro by anthracyclines can be used to vaccinate the immunocompetent host against the subsequent inoculation of living cancer cells. The elevated ATP content of the TME on one hand allows the generation of large amounts of adenosine, thus enhancing immunosuppression, and on the other increases immune cell recruitment and tumor antigen presentation, thus promoting anti-tumor immunity. ${ }^{165}$ In keeping with these findings, we and others recently demonstrated that B16 melanomas, CT26 colon carcinomas and colitis-associated cancer grow faster in P2X7R-KO versus P2X7R-wt hosts. ${ }^{117,166}$ In the B16 melanoma and in the CT26 colon carcinoma model of transplanted tumor, the lack of host P2X7R caused a striking reduction in tumor infiltration inflammatory cells, ${ }^{117}$ whereas in colitis-associated carcinoma the inflammatory infiltrate did not show substantial quantitative alterations but harbored an increased amount of $\mathrm{FOXP3}^{+}$ regulatory T cells. ${ }^{166}$

Preclinical data from P2X7R-wt and P2X7R-KO models emphasize the dual role played by this receptor in cancer growth. In the P2X7R-KO host, the immune response is crippled from the very early phases of tumor growth, which leads either to alterations in the inflammatory infiltrate or to the outright absence of infiltrating cells, suggesting that a functional P2X7R is necessary for an efficient presentation of tumor antigens and the following activation of the immune response. ${ }^{117,166}$ In the case of tumors transplanted into P2X7R-wt host, it is likely that the fast tumor growth recruits an inflammatory infiltrate rich in P2X7R-positive cells with immunosuppressive activity (M2 macrophages, MDSCs). Collectively, these observations on one hand highlight the complexity of a therapeutic approach simply based on P2RX7 targeting, not dissimilarly from consolidated preclinical and clinical observations derived from the protocols based on hitting a single cellular target, but on the other show that blocking ATP/ ADP/AMP hydrolysis might allow to shift the balance in the TME from immunosuppression to immunostimulation.

The high ATP content of the TME has also direct effects on the tumor cells. In general, pharmacologic ATP doses are cytotoxic to most cells expressing the P2X7R. ${ }^{167}$ Some exceptions are known among human tumors, for example, human neuroblastoma, where uncoupling from the intracellular cell death machinery (for example, caspase 3 activation) is thought to be responsible for refractoriness to P2X7R-mediated cell death. ${ }^{107}$ How and if ATP is responsible for tumor-associated necrosis is not known, albeit experiments by Burnstock and co-workers show that ATP administration causes tumor regression, possibly by causing tumor necrosis. ${ }^{168}$ On the other hand, ATP might directly stimulate tumor cell growth acting at P2YRs as well as P2X7R, and possibly $\mathrm{P} 2 \mathrm{X} 3 \mathrm{R}^{85,102,109,133}$ All evidence suggest that the P2X7R is a crucial determinant of the effects of ATP in host-tumor interaction. The P2X7R may sensitize tumor cells to the cytotoxic effects of extracellular ATP, but may also stimulate tumor cell growth. Most malignant tumors express this receptor, and accordingly pharmacological P2X7R blockade or silencing have a striking in vivo anti- 
tumor effect. ${ }^{104,109,117,121,125,169}$ These observations show that, at least in in vivo models of transplanted tumors, the overall effect of P2X7R targeting is beneficial. P2X7R targeting might be a viable therapeutic option also in the light of the role played by this receptor in the release of suppressive factors from MDSCs. ${ }^{33}$ Blocking MDSC P2X7R might help relieve immunosuppression in the TME and thus restore an efficient anti-tumor response. If this hypothesis was true, P2X7R blockers should be more effective in the immunocompetent than in the immunocompromised host. A recent study by Amoroso et al. supports this hypothesis by showing increased efficacy of P2X7R blockade in reducing neuroblastoma growth and vascularization in albino $J$ versus nude/nude mice. ${ }^{104}$ In any case, a P2X7R-targeted therapy will be only meaningful in the presence of P2X7R-expressing tumors as preclinical data show that P2X7R blockade has little efficacy against tumors with low or no P2X7R expression. ${ }^{109}$ In a therapeutic perspective, heterogeneity of $P 2 X 7 R$ expression by different tumors might be a complicating factor, but this is not new in receptor-targeted cancer therapeutics.

\section{CONCLUSIONS}

There is now growing consensus that ATP and adenosine are fundamental components of the TME, where they affect tumor growth, immune cell functions and tumor-host interaction in different ways. Given the widespread observation that many malignant tumors overexpress several P1R or P2R subtypes, a simplistic approach would entail to target these receptors with selective blockers, with the aim to suppress tumor cell growth. On the same line of intervention, enzymes involved in the metabolism of extracellular nucleotides and nucleosides (CD39, CD73 and adenosine deaminase) are viewed as an obvious target. However, this simplistic approach, despite its proved efficacy in several preclinical tumor models, is clearly very naive. P1Rs, P2Rs and ATP/adenosine-degrading enzymes are expressed on the tumor as well as on the host immune and stromal cells, where they are endowed with crucial functions in host-tumor interaction. Careful choice of the candidate target purinergic receptor in association with modulators of extracellular adenosinergic pathways might allow to inhibit tumor cell growth and at the same time to enhance the anti-tumor host response. Hopefully, this will provide an additional powerful weapon for novel anti-cancer combinatorial therapies.

\section{CONFLICT OF INTEREST}

The authors declare no conflict of interest.

\section{ACKNOWLEDGEMENTS}

FDV is supported by grants from AIRC (no. IG 13025), Telethon (no. GGP 11014), ERANET Neuron 'Nanostroke', EU COST Program no. BM1406, the Ministry of Health of Italy (no. RF-2011-02348435), the Italian Ministry of Education, University and Research (no. RBAP11FXBC_001) and funds from the University of Ferrara. FDV was also supported by the 7th Framework Program HEALTH-F2-2007-202231 'ATPBone'. EA is supported by AIRC (IG16812), a Young investigator grant of the Region Emilia Romagna (Bando Alessandro Liberati) and Institutional funds from the University of Ferrara.

\section{REFERENCES}

1 Drury AN, Szent-Gyorgy A. The physiological activity of adenine compounds with special reference to their action upon the mammalian heart. J Physiol 1929; 68: 213-237.

2 Lohmann K. Uber die pyrophosphatfraktion im muskel. Naturwissenschaften 1929; 17: 624-625.

3 Burnstock G. Pathophysiology and therapeutic potential of purinergic signaling. Pharmacol Rev 2006; 58: 58-86.
4 Burnstock G. Purinergic signalling: from discovery to current developments. Exp Physiol 2014; 99: 16-34.

5 Webb TE, Simon J, Krishek BJ, Bateson AN, Smart TG, King BF et al. Cloning and functional expression of a brain G-protein-coupled ATP receptor. FEBS Lett 1993; 324: 219-225.

6 Brake AJ, Wagenbach MJ, Julius D. New structural motif for ligand-gated ion channels defined by an ionotropic ATP receptor. Nature 1994; 371: 519-523.

7 Valera S, Hussy N, Evans RJ, Adami N, North RA, Surprenant A et al. A new class of ligand-gated ion channel defined by $\mathrm{P} 2 \mathrm{x}$ receptor for extracellular ATP. Nature 1994; 371: 516-519.

8 Bours MJ, Dagnelie PC, Giuliani AL, Wesselius A, Di Virgilio F. P2 receptors and extracellular ATP: a novel homeostatic pathway in inflammation. Front Biosci (Schol Ed) 2011; 3: 1443-1456.

9 Khakh BS, North RA. P2X receptors as cell-surface ATP sensors in health and disease. Nature 2006; 442: 527-532.

10 Idzko M, Ferrari D, Eltzschig HK. Nucleotide signalling during inflammation. Nature 2014; 509: 310-317.

11 Antonioli L, Blandizzi C, Pacher P, Hasko G. Immunity, inflammation and cancer: a leading role for adenosine. Nat Rev Cancer 2013; 13: 842-857.

12 Rossi L, Manfredini R, Bertolini F, Ferrari D, Fogli M, Zini R et al. The extracellular nucleotide UTP is a potent inducer of hematopoietic stem cell migration. Blood 2007; 109: 533-542.

13 Rossi L, Salvestrini V, Ferrari D, Di Virgilio F, Lemoli RM. The sixth sense: hematopoietic stem cells detect danger through purinergic signaling. Blood 2012; 120: 2365-2375.

14 Lazarowski ER, Harden TK. UDP-sugars as extracellular signaling molecules: cellular and physiologic consequences of $\mathrm{P} 2 \mathrm{Y} 14$ receptor activation. Mol Pharmacol 2015; 88: 151-160.

15 Koizumi S, Shigemoto-Mogami Y, Nasu-Tada K, Shinozaki Y, Ohsawa K, Tsuda M et al. UDP acting at P2Y6 receptors is a mediator of microglial phagocytosis. Nature 2007; 446: 1091-1095.

16 Jacobson KA, Muller CE. Medicinal chemistry of adenosine, P2Y and P2X receptors. Neuropharmacology 2016; 104: 31-49.

17 Lazarowski ER. Vesicular and conductive mechanisms of nucleotide release. Purinergic Signal 2012; 8: 359-373.

18 Jin X, Shepherd RK, Duling BR, Linden J. Inosine binds to A3 adenosine receptors and stimulates mast cell degranulation. J Clin Invest 1997; 100: 2849-2857.

19 Young JD, Yao SY, Baldwin JM, Cass CE, Baldwin SA. The human concentrative and equilibrative nucleoside transporter families, SLC28 and SLC29. Mol Aspects Med 2013; 34: 529-547.

20 Zimmermann $\mathrm{H}$. Extracellular metabolism of ATP and other nucleotides. Naunyn Schmiedebergs Arch Pharmacol 2000; 362: 299-309.

21 Longhi MS, Robson SC, Bernstein SH, Serra S, Deaglio S. Biological functions of ecto-enzymes in regulating extracellular adenosine levels in neoplastic and inflammatory disease states. J Mol Med (Berl) 2013; 91: 165-172.

22 Falzoni S, Donvito G, Di Virgilio F. Detecting adenosine triphosphate in the pericellular space. Interface Focus 2013; 3: 20120101.

23 Yegutkin GG. Enzymes involved in metabolism of extracellular nucleotides and nucleosides: Functional implications and measurement of activities. Crit Rev Biochem Mol Biol 2014; 49: 473-497.

24 Beigi R, Kobatake E, Aizawa M, Dubyak GR. Detection of local ATP release from activated platelets using cell surface-attached firefly luciferase. Am J Physiol 1999; 276: 267-278.

25 Schneider SW, Egan ME, Jena BP, Guggino WB, Oberleithner H, Geibel JP. Continuous detection of extracellular ATP on living cells by using atomic force microscopy. Proc Natl Acad Sci USA 1999; 96: 12180-12185.

26 Hayashi S, Hazama A, Dutta AK, Sabirov RZ, Okada Y. Detecting ATP release by a biosensor method. Sci STKE 2004; 2004: I14.

27 Corriden R, Insel PA, Junger WG. A novel method using fluorescence microscopy for real-time assessment of ATP release from individual cells. Am J Physiol Cell Physiol 2007; 293: C1420-C1425.

28 Llaudet E, Hatz S, Droniou M, Dale N. Microelectrode biosensor for real-time measurement of ATP in biological tissue. Anal Chem 2005; 77: 3267-3273.

29 Pellegatti P, Falzoni S, Pinton P, Rizzuto R, Di Virgilio F. A novel recombinant plasma membrane-targeted luciferase reveals a new pathway for ATP secretion. Mol Biol Cell 2005; 16: 3659-3665.

30 Wilhelm K, Ganesan J, Muller T, Durr C, Grimm M, Beilhack A et al. Graftversus-host disease is enhanced by extracellular ATP activating P2X7R. Nat Med 2010; 16: 1434-1438.

31 Weber FC, Esser PR, Muller T, Ganesan J, Pellegatti P, Simon MM et al. Lack of the purinergic receptor $\mathrm{P} 2 \mathrm{X}(7)$ results in resistance to contact hypersensitivity. $J$ Exp Med 2010; 207: 2609-2619.

32 Barbera-Cremades M, Baroja-Mazo A, Gomez Al, Machado F, Di Virgilio F, Pelegrin P. P2X7 receptor-stimulation causes fever via PGE2 and IL-1beta release. FASEB J 2012; 26: 2951-2962. 
33 Bianchi G, Vuerich M, Pellegatti P, Marimpietri D, Emionite L, Marigo I et al. ATP/P2X7 axis modulates myeloid-derived suppressor cell functions in neuroblastoma microenvironment. Cell Death Dis 2014; 5: e1135.

34 Loo JM, Scherl A, Nguyen A, Man FY, Weinberg E, Zeng Z et al. Extracellular metabolic energetics can promote cancer progression. Cell 2015; 160: 393-406.

35 Pellegatti P, Raffaghello L, Bianchi G, Piccardi F, Pistoia V, Di Virgilio F. Increased level of extracellular ATP at tumor sites: in vivo imaging with plasma membrane luciferase. PLoS One 2008; 3: e2599.

36 Ohta A, Gorelik E, Prasad SJ, Ronchese F, Lukashev D, Wong MK et al. A2A adenosine receptor protects tumors from antitumor T cells. Proc Natl Acad Sci USA 2006; 103: 13132-13137.

37 Blay J, White TD, Hoskin DW. The extracellular fluid of solid carcinomas contains immunosuppressive concentrations of adenosine. Cancer Res 1997; 57: 2602-2605.

38 Stagg J, Smyth MJ. Extracellular adenosine triphosphate and adenosine in cancer. Oncogene 2010; 29: 5346-5358.

39 Bastid J, Cottalorda-Regairaz A, Alberici G, Bonnefoy N, Eliaou JF, Bensussan A ENTPD1/CD39 is a promising therapeutic target in oncology. Oncogene 2013; 32: 1743-1751.

40 Cappellari AR, Rockenbach L, Dietrich F, Clarimundo V, Glaser T, Braganhol E et al. Characterization of ectonucleotidases in human medulloblastoma cell lines: ecto-5'NT/CD73 in metastasis as potential prognostic factor. PLoS One 2012; 7: e47468.

41 Kunzli BM, Bernlochner MI, Rath S, Kaser S, Csizmadia E, Enjyoji K et al. Impact of CD39 and purinergic signalling on the growth and metastasis of colorectal cancer. Purinergic Signal 2011; 7: 231-241.

42 Aliagas E, Vidal A, Texido L, Ponce J, Condom E, Martin-Satue M. High expression of ecto-nucleotidases CD39 and CD73 in human endometrial tumors. Mediators Inflamm 2014; 2014: 509027.

43 Abbracchio MP, Burnstock G, Boeynaems JM, Barnard EA, Boyer JL, Kennedy C et al. International Union of Pharmacology LVIII: update on the P2Y G proteincoupled nucleotide receptors: from molecular mechanisms and pathophysiology to therapy. Pharmacol Rev 2006; 58: 281-341.

44 Surprenant A, North RA. Signaling at purinergic P2X receptors. Annu Rev Physiol 2009; 71: 333-359.

45 Cockcroft S, Gomperts BD. ATP induces nucleotide permeability in rat mast cells. Nature 1979; 279: 541-542.

46 Steinberg TH, Silverstein SC. Extracellular ATP4- promotes cation fluxes in the J774 mouse macrophage cell line. J Biol Chem 1987; 262: 3118-3122.

47 Virginio C, MacKenzie A, Rassendren FA, North RA, Surprenant A. Pore dilation of neuronal P2X receptor channels. Nat Neurosci 1999; 2: 315-321.

48 Khakh BS, Bao XR, Labarca C, Lester HA. Neuronal P2X transmitter-gated cation channels change their ion selectivity in seconds. Nat Neurosci 1999; 2: 322-330.

49 Di Virgilio F. ATP permeabilization. Cell and Tissue Culture: Laboratory Procedures. In: Doyle A, Griffiths JB, Newell DG (eds). John Wiley and Sons: New York, NY, USA, 1994.

50 Surprenant A, Rassendren F, Kawashima E, North RA, Buell G. The cytolytic P2Z receptor for extracellular ATP identified as a P2X receptor (P2X7). Science 1996; 272: 735-738.

51 Wiley JS, Chen JR, Snook MB, Jamieson GP. The P2Z-purinoceptor of human lymphocytes: actions of nucleotide agonists and irreversible inhibition by oxidized ATP. Br J Pharmacol 1994; 112: 946-950.

52 Li M, Toombes GE, Silberberg SD, Swartz KJ. Physical basis of apparent pore dilation of ATP-activated P2X receptor channels. Nat Neurosci 2015; 18: 1577-1583.

53 Compan V, Ulmann L, Stelmashenko O, Chemin J, Chaumont S, Rassendren F. P2X2 and P2X5 Subunits Define a New Heteromeric Receptor with P2X7-Like Properties. J Neurosci 2012; 32: 4284-4296.

54 Jiang LH, Rassendren F, Mackenzie A, Zhang YH, Surprenant A, North RA $\mathrm{N}$-methyl-D-glucamine and propidium dyes utilize different permeation pathways at rat P2X7 receptors. Am J Physiol Cell Physiol 2005; 289: C1295-C1302.

55 Coddou C, Yan Z, Obsil T, Huidobro-Toro JP, Stojilkovic SS. Activation and regulation of purinergic P2X receptor channels. Pharmacol Rev 2011; 63 : 641-683

56 Pelegrin $P$, Surprenant A. Pannexin-1 mediates large pore formation and interleukin-1beta release by the ATP-gated P2X7 receptor. EMBO J 2006; 25: 5071-5082.

57 Allsopp RC, Evans RJ. Contribution of the juxtatransmembrane intracellular regions to the time course and permeation of ATP-gated P2X7 receptor ion channels. J Biol Chem 2015; 290: 14556-14566.

58 Ferrari D, Pizzirani C, Adinolfi E, Forchap S, Sitta B, Turchet L et al. The antibiotic polymyxin B modulates P2X7 receptor function. J Immunol 2004; 173: 4652-4660.
59 Gessi S, Merighi S, Sacchetto V, Simioni C, Borea PA. Adenosine receptors and cancer. Biochim Biophys Acta 2011; 1808: 1400-1412.

60 Gines S, Hillion J, Torvinen M, Le CS, Casado V, Canela El et al. Dopamine D1 and adenosine $\mathrm{A} 1$ receptors form functionally interacting heteromeric complexes. Proc Natl Acad Sci USA 2000; 97: 8606-8611.

61 Corriden R, Kilpatrick LE, Kellam B, Briddon SJ, Hill SJ. Kinetic analysis of antagonist-occupied adenosine-A3 receptors within membrane microdomains of individual cells provides evidence of receptor dimerization and allosterism. FASEB J 2014; 28: 4211-4222.

62 Young A, Mittal D, Stagg J, Smyth MJ. Targeting cancer-derived adenosine: new therapeutic approaches. Cancer Discov 2014; 4: 879-888.

63 Mandapathil M, Hilldorfer B, Szczepanski MJ, Czystowska M, Szajnik M, Ren J et al. Generation and accumulation of immunosuppressive adenosine by human CD4+CD25highFOXP3+ regulatory T cells. J Biol Chem 2010; 285: 7176-7186.

64 MacKenzie WM, Hoskin DW, Blay J. Adenosine inhibits the adhesion of anti-CD3activated killer lymphocytes to adenocarcinoma cells through an A3 receptor. Cancer Res 1994; 54: 3521-3526.

65 Hoskin DW, Butler JJ, Drapeau D, Haeryfar SM, Blay J. Adenosine acts through an A3 receptor to prevent the induction of murine anti-CD3-activated killer T cells. Int J Cancer 2002; 99: 386-395.

66 Ohta A, Sitkovsky M. Role of G-protein-coupled adenosine receptors in downregulation of inflammation and protection from tissue damage. Nature 2001; 414: 916-920.

67 Hasko G, Linden J, Cronstein B, Pacher P. Adenosine receptors: therapeutic aspects for inflammatory and immune diseases. Nat Rev Drug Discov 2008; 7 759-770.

68 Linden J, Cekic C. Regulation of lymphocyte function by adenosine. Arterioscler Thromb Vasc Biol 2012; 32: 2097-2103.

69 Mirza A, Basso A, Black S, Malkowski M, Kwee L, Pachter JA et al. RNA interference targeting of A1 receptor-overexpressing breast carcinoma cells leads to diminished rates of cell proliferation and induction of apoptosis. Cancer Biol Ther 2005; 4: 1355-1360.

70 Lin Z, Yin P, Reierstad S, O'Halloran M, Coon VJ, Pearson EK et al. Adenosine A1 receptor, a target and regulator of estrogen receptoralpha action, mediates the proliferative effects of estradiol in breast cancer. Oncogene 2010; 29: 1114-1122.

71 Mousavi S, Panjehpour M, Izadpanahi MH, Aghaei M. Expression of adenosine receptor subclasses in malignant and adjacent normal human prostate tissues. Prostate 2015; 75: 735-747.

72 Bowser JL, Blackburn MR, Shipley GL, Molina JG, Dunner K Jr., Broaddus RR. Loss of CD73-mediated actin polymerization promotes endometrial tumor progression. J Clin Invest 2016; 126: 220-238.

73 Etique N, Grillier-Vuissoz I, Lecomte J, Flament S. Crosstalk between adenosine receptor (A2A isoform) and ERalpha mediates ethanol action in MCF-7 breast cancer cells. Oncol Rep 2009; 21: 977-981.

74 Merighi S, Mirandola P, Milani D, Varani K, Gessi S, Klotz KN et al. Adenosine receptors as mediators of both cell proliferation and cell death of cultured human melanoma cells. J Invest Dermatol 2002; 119: 923-933.

75 Kasama H, Sakamoto Y, Kasamatsu A, Okamoto A, Koyama T, Minakawa Y et al. Adenosine $\mathrm{A} 2 \mathrm{~b}$ receptor promotes progression of human oral cancer. $B M C$ Cancer 2015; 15: 563.

76 Ntantie E, Gonyo P, Lorimer EL, Hauser AD, Schuld N, McAllister D et al. An adenosine-mediated signaling pathway suppresses prenylation of the GTPase Rap1B and promotes cell scattering. Sci Signal 2013; 6: ra39.

77 Cekic C, Sag D, Li Y, Theodorescu D, Strieter RM, Linden J. Adenosine A2B receptor blockade slows growth of bladder and breast tumors. J Immunol 2012; 188: 198-205.

78 Gessi S, Cattabriga E, Avitabile A, Gafa' R, Lanza G, Cavazzini L et al. Elevated expression of $\mathrm{A} 3$ adenosine receptors in human colorectal cancer is reflected in peripheral blood cells. Clin Cancer Res 2004; 10: 5895-5901.

79 Fishman P, Bar-Yehuda S, Ohana G, Barer F, Ochaion A, Erlanger A et al. An agonist to the $A 3$ adenosine receptor inhibits colon carcinoma growth in mice via modulation of GSK-3 beta and NF-kappa B. Oncogene 2004; 23: 2465-2471.

80 Gessi S, Sacchetto V, Fogli E, Merighi S, Varani K, Baraldi PG et al. Modulation of metalloproteinase-9 in U87MG glioblastoma cells by $A 3$ adenosine receptors. Biochem Pharmacol 2010; 79: 1483-1495.

81 Jajoo S, Mukherjea D, Watabe K, Ramkumar V. Adenosine A(3) receptor suppresses prostate cancer metastasis by inhibiting NADPH oxidase activity. Neoplasia 2009; 11: 1132-1145.

82 Madi L, Ochaion A, Rath-Wolfson L, Bar-Yehuda S, Erlanger A, Ohana G et al. The A3 adenosine receptor is highly expressed in tumor versus normal cells: potential target for tumor growth inhibition. Clin Cancer Res 2004; 10: 4472-4479.

83 Borea PA, Varani K, Vincenzi F, Baraldi PG, Tabrizi MA, Merighi S et al. The A3 adenosine receptor: history and perspectives. Pharmacol Rev 2015; 67: 74-102. 
84 Stemmer SM, Benjaminov O, Medalia G, Ciuraru NB, Silverman MH, Bar-Yehuda S et al. CF102 for the treatment of hepatocellular carcinoma: a phase I/II, open-label, dose-escalation study. Oncologist 2013; 18: 25-26.

85 Burnstock G, Di Virgilio F. Purinergic signalling and cancer. Purinergic Signal 2013; 9: $491-540$

86 Xie R, Xu J, Wen G, Jin H, Liu X, Yang Y et al. The P2Y2 nucleotide receptor mediates the proliferation and migration of human hepatocellular carcinoma cells induced by ATP. J Biol Chem 2014; 289: 19137-19149.

87 Li WH, Qiu Y, Zhang HQ, Tian XX, Fang WG. P2Y2 Receptor and EGFR Cooperate to Promote Prostate Cancer Cell Invasion via ERK1/2 Pathway. PLoS One 2015; 10: e0133165.

88 Chadet S, Jelassi B, Wannous R, Angoulvant D, Chevalier S, Besson P et al. The activation of $\mathrm{P} 2 \mathrm{Y} 2$ receptors increases MCF-7 breast cancer cells migration through the MEK-ERK1/2 signalling pathway. Carcinogenesis 2014; 35: 1238-1247.

89 Li WH, Qiu Y, Zhang HQ, Liu Y, You JF, Tian XX et al. P2Y2 receptor promotes cell invasion and metastasis in prostate cancer cells. Br J Cancer 2013; 109: 1666-1675.

90 Joo YN, Jin H, Eun SY, Park SW, Chang KC, Kim HJ. P2Y2R activation by nucleotides released from the highly metastatic breast cancer cell MDA-MB-231 contributes to pre-metastatic niche formation by mediating lysyl oxidase secretion, collagen crosslinking, and monocyte recruitment. Oncotarget 2014; 5: 9322-9334.

91 Yang G, Zhang S, Zhang Y, Zhou Q, Peng S, Zhang T et al. The inhibitory effects of extracellular ATP on the growth of nasopharyngeal carcinoma cells via P2Y2 receptor and osteopontin. J Exp Clin Cancer Res 2014; 33: 53.

92 Coutinho-Silva R, Stahl L, Cheung KK, de Campos NE, de Oliveira SC, Ojcius DM et al. P2X and P2Y purinergic receptors on human intestinal epithelial carcinoma cells: effects of extracellular nucleotides on apoptosis and cell proliferation. Am J Physiol Gastrointest Liver Physiol 2005; 288: G1024-G1035.

93 Stegner D, Dutting S, Nieswandt B. Mechanistic explanation for platelet contribution to cancer metastasis. Thromb Res 2014; 133(Suppl 2): S149-S157.

94 Reymond N, d'Agua BB, Ridley AJ. Crossing the endothelial barrier during metastasis. Nat Rev Cancer 2013; 13: 858-870.

95 Schumacher D, Strilic B, Sivaraj KK, Wettschureck N, Offermanns S. Platelet-derived nucleotides promote tumor-cell transendothelial migration and metastasis via P2Y2 receptor. Cancer Cell 2013; 24: 130-137.

96 Wilson FH, Johannessen CM, Piccioni F, Tamayo P, Kim JW, Van Allen EM et al. A functional landscape of resistance to ALK inhibition in lung cancer. Cancer Cell 2015; 27: 397-408.

97 Di Virgilio F. Purines, purinergic receptors, and cancer. Cancer Res 2012; 72: 5441-5447.

98 Di Virgilio F, Bronte V, Collavo D, Zanovello P. Responses of mouse lymphocytes to extracellular adenosine 5'-triphosphate (ATP). Lymphocytes with cytotoxic activity are resistant to the permeabilizing effects of ATP. J Immunol 1989; 143: 1955-1960.

99 Di Virgilio F, Chiozzi P, Falzoni S, Ferrari D, Sanz JM, Venketaraman V et al. Cytolytic P2X purinoceptors. Cell Death Differ 1998; 5: 191-199.

100 Baricordi OR, Ferrari D, Melchiorri L, Chiozzi P, Hanau S, Chiari E et al. An ATPactivated channel is involved in mitogenic stimulation of human $T$ lymphocytes. Blood 1996; 87: 682-690.

101 Adinolfi E, Melchiorri L, Falzoni S, Chiozzi P, Morelli A, Tieghi A et al. P2X7 receptor expression in evolutive and indolent forms of chronic B lymphocytic leukemia. Blood 2002; 99: 706-708.

102 Adinolfi E, Callegari MG, Ferrari D, Bolognesi C, Minelli M, Wieckowski MR et al. Basal activation of the P2X7 ATP Receptor elevates mitochondrial calcium and potential, increases cellular ATP levels, and promotes serumindependent growth. Mol Biol Cell 2005; 16: 3260-3272.

103 Amoroso F, Falzoni S, Adinolfi E, Ferrari D, Di Virgilio F. The P2X7 receptor is a key modulator of aerobic glycolysis. Cell Death Dis 2012; 3: e370.

104 Amoroso F, Capece M, Rotondo A, Cangelosi D, Ferracin M, Franceschini A et al. The P2X7 receptor is a key modulator of the PI3K/GSK3beta/VEGF signaling network: evidence in experimental neuroblastoma. Oncogene 2015; 34: 5240-5251.

105 Monif M, Reid CA, Powell KL, Smart ML, Williams DA. The P2X7 Receptor Drives Microglial Activation and Proliferation: A Trophic Role for P2X7R Pore. J Neurosci 2009; 29: 3781-3791.

106 Bianco F, Ceruti S, Colombo A, Fumagalli M, Ferrari D, Pizzirani C et al. A role for P2X7 in microglial proliferation. J Neurochem 2006; 99: 745-758.

107 Raffaghello L, Chiozzi P, Falzoni S, Di Virgilio F, Pistoia V. The P2X7 receptor sustains the growth of human neuroblastoma cells through a substance P-dependent mechanism. Cancer Res 2006; 66: 907-914.

108 Rigato C, Swinnen N, Buckinx R, Couillin I, Mangin JM, Rigo JM et al. Microglia proliferation is controlled by $\mathrm{P} 2 \mathrm{X} 7$ receptors in a Pannexin-1-independent manner during early embryonic spinal cord invasion. J Neurosci 2012; 32: 11559-11573.

109 Adinolfi E, Raffaghello L, Giuliani AL, Cavazzini L, Capece M, Chiozzi P et al. Expression of P2X7 receptor increases in vivo tumor growth. Cancer Res 2012; 72: 2957-2969.

110 Thompson BA, Storm MP, Hewinson J, Hogg S, Welham MJ, Mackenzie AB. A novel role for $\mathrm{P} 2 \mathrm{X} 7$ receptor signalling in the survival of mouse embryonic stem cells. Cell Signal 2012; 24: 770-778.

111 Vazquez-Cuevas FG, Martinez-Ramirez AS, Robles-Martinez L, Garay E, Garcia-Carranca A, Perez-Montiel D et al. Paracrine stimulation of P2X7 receptor by ATP activates a proliferative pathway in ovarian carcinoma cells. J Cell Biochem 2014; 115: 1955-1966.

112 Giannuzzo A, Pedersen SF, Novak I. The P2X7 receptor regulates cell survival, migration and invasion of pancreatic ductal adenocarcinoma cells. Mol Cancer 2015; 14: 203.

113 Gomez-Villafuertes R, Garcia-Huerta P, Diaz-Hernandez Jl, Miras-Portugal MT. $\mathrm{PI3K} /$ Akt signaling pathway triggers $\mathrm{P} 2 \mathrm{X} 7$ receptor expression as a pro-survival factor of neuroblastoma cells under limiting growth conditions. Sci Rep 2015; 5: 18417.

114 Adinolfi E, Capece M, Amoroso F, De Marchi E, Franceschini A. Emerging roles of P2X receptors in cancer. Curr Med Chem 2015; 22: 878-890.

115 Giuliani AL, Colognesi D, Ricco T, Roncato C, Capece M, Amoroso F et al. Trophic activity of human $\mathrm{P} 2 \mathrm{X} 7$ receptor isoforms $\mathrm{A}$ and $\mathrm{B}$ in osteosarcoma. PLoS One 2014; 9: e107224.

116 De Marchi E, Orioli E, Dal Ben D, Adinolfi E. P2X7 receptor as a therapeutic target. Adv Protein Chem Struct Biol 2016; 104: 39-79.

117 Adinolfi E, Capece M, Franceschini A, Falzoni S, Giuliani AL, Rotondo A et al. Accelerated tumor progression in mice lacking the ATP receptor P2X7. Cancer Res 2015; 75: 635-644.

118 Jacques-Silva MC, Rodnight R, Lenz G, Liao Z, Kong Q, Tran M et al. P2X7 receptors stimulate AKT phosphorylation in astrocytes. Br J Pharmacol 2004; 141: 1106-1117.

119 Adinolfi E, Callegari MG, Cirillo M, Pinton P, Giorgi C, Cavagna D et al. Expression of the P2X7 receptor increases the Ca2+ content of the endoplasmic reticulum, activates NFATc1 and protects from apoptosis. I Biol Chem 2009; 284: 10120-10128.

120 Tafani M, Schito L, Pellegrini L, Villanova L, Marfe G, Anwar T et al. Hypoxia-increased RAGE and P2X7R expression regulates tumor cell invasion through phosphorylation of Erk $1 / 2$ and Akt and nuclear translocation of NF-\{kappa\}B. Carcinogenesis 2011; 32: 1167-1175.

121 Qiu Y, Li WH, Zhang HQ, Liu Y, Tian XX, Fang WG. P2X7 mediates ATP-driven invasiveness in prostate cancer cells. PLoS One 2014; 9: e114371.

122 Adinolfi E, Cirillo M, Woltersdorf R, Falzoni S, Chiozzi P, Pellegatti $P$ et al. Trophic activity of a naturally occurring truncated isoform of the $\mathrm{P} 2 \mathrm{X} 7$ receptor. FASEB J 2010; 24: 3393-3404.

123 Jelassi B, Chantome A, Alcaraz-Perez F, Baroja-Mazo A, Cayuela ML, Pelegrin P et al. P2X(7) receptor activation enhances SK3 channels- and cystein cathepsindependent cancer cells invasiveness. Oncogene 2011; 30: 2108-2122.

124 Takai E, Tsukimoto M, Harada H, Kojima S. Autocrine signaling via release of ATP and activation of $\mathrm{P} 2 \mathrm{X} 7$ receptor influences motile activity of human lung cancer cells. Purinergic Signal 2014; 10: 487-497.

125 Xia J, Yu X, Tang L, Li G, He T. P2X7 receptor stimulates breast cancer cell invasion and migration via the AKT pathway. Oncol Rep 2015; 34: 103-110.

126 Chong JH, Zheng GG, Zhu XF, Guo Y, Wang L, Ma CH et al. Abnormal expression of P2X family receptors in Chinese pediatric acute leukemias. Biochem Biophys Res Commun 2010; 391: 498-504.

127 Kwon JH, Nam ES, Shin HS, Cho SJ, Park HR, Kwon MJ. P2X7 receptor expression in coexistence of papillary thyroid carcinoma with Hashimoto's thyroiditis. Korean J Pathol 2014; 48: 30-35.

128 Ghalali A, Wiklund F, Zheng H, Stenius U, Hogberg J. Atorvastatin prevents ATP-driven invasiveness via P2X7 and EHBP1 signaling in PTEN-expressing prostate cancer cells. Carcinogenesis 2014; 35: 1547-1555.

129 Roger S, Jelassi B, Couillin I, Pelegrin P, Besson P, Jiang L. Understanding the roles of the $\mathrm{P} 2 \mathrm{X} 7$ receptor in solid tumour progression and therapeutic perspectives. Biochim Biophys Acta 2014; 1848: 2584-2602.

130 Solini A, Simeon V, Derosa L, Orlandi P, Rossi C, Fontana A et al. Genetic interaction of $\mathrm{P} 2 \mathrm{X} 7$ receptor and VEGFR-2 polymorphisms identifies a favorable prognostic profile in prostate cancer patients. Oncotarget 2015; 6: 28743-28754.

131 Hill LM, Gavala ML, Lenertz LY, Bertics PJ. Extracellular ATP may contribute to tissue repair by rapidly stimulating purinergic receptor $\mathrm{X} 7$-dependent vascular endothelial growth factor release from primary human monocytes. $J$ Immunol 2010; 185: 3028-3034. 
132 Tung HC, Lee FY, Wang SS, Tsai MH, Lee JY, Huo Tl et al. The Beneficial Effects of P2X7 Antagonism in Rats with Bile Duct Ligation-induced Cirrhosis. PLoS One 2015; 10: e0124654.

133 Maynard JP, Lee JS, Sohn BH, Yu X, Lopez-Terrada D, Finegold MJ et al. $\mathrm{P} 2 \mathrm{X} 3$ purinergic receptor overexpression is associated with poor recurrencefree survival in hepatocellular carcinoma patients. Oncotarget 2015; 6: 41162-41179.

134 Greig AV, Linge C, Healy V, Lim P, Clayton E, Rustin MH et al. Expression of purinergic receptors in non-melanoma skin cancers and their functional roles in A431 cells. J Invest Dermatol 2003; 121: 315-327.

135 Le KT, Paquet M, Nouel D, Babinski K, Seguela P. Primary structure and expression of a naturally truncated human P2X ATP receptor subunit from brain and immune system. FEBS Lett 1997; 418: 195-199.

136 Kotnis S, Bingham B, Vasilyev DV, Miller SW, Bai Y, Yeola S et al. Genetic and functional analysis of human P2X5 reveals a distinct pattern of exon 10 polymorphism with predominant expression of the nonfunctional receptor isoform. Mol Pharmacol 2010; 77: 953-960.

137 de Rijke B, van Horssen-Zoetbrood A, Beekman JM, Otterud B, Maas F, Woestenenk $R$ et al. A frameshift polymorphism in P2X5 elicits an allogeneic cytotoxic $T$ lymphocyte response associated with remission of chronic myeloid leukemia. J Clin Invest 2005; 115: 3506-3516.

138 Overes IM, de RB, van Horssen-Zoetbrood A, Fredrix $\mathrm{H}$, de Graaf AO, Jansen JH et al. Expression of $\mathrm{P} 2 \mathrm{X} 5$ in lymphoid malignancies results in $\mathrm{LRH}-1$-specific cytotoxic T-cell-mediated lysis. Br J Haematol 2008; 141: 799-807.

139 Norde WJ, Overes IM, Maas F, Fredrix H, Vos JC, Kester MG et al. Myeloid leukemic progenitor cells can be specifically targeted by minor histocompatibility antigen LRH-1-reactive cytotoxic T cells. Blood 2009; 113: 2312-2323.

140 Leclerc BG, Charlebois R, Chouinard G, Allard B, Pommey S, Saad F et al. CD73 Expression Is an Independent Prognostic Factor in Prostate Cancer. Clin Cancer Res 2016; 22: 158-166.

141 Synnestvedt K, Furuta GT, Comerford KM, Louis N, Karhausen J, Eltzschig HK et al. Ecto-5'-nucleotidase (CD73) regulation by hypoxia-inducible factor-1 mediates permeability changes in intestinal epithelia. J Clin Invest 2002; 110: 993-1002.

142 Jackson SW, Hoshi T, Wu Y, Sun X, Enjyoji K, Cszimadia E et al. Disordered purinergic signaling inhibits pathological angiogenesis in cd39/Entpd1null mice. Am J Pathol 2007; 171: 1395-1404.

143 Stagg J, Divisekera U, Duret H, Sparwasser T, Teng MW, Darcy PK et al. CD73-deficient mice have increased antitumor immunity and are resistant to experimental metastasis. Cancer Res 2011; 71: 2892-2900.

144 Loi S, Pommey S, Haibe-Kains B, Beavis PA, Darcy PK, Smyth MJ et al. CD73 promotes anthracycline resistance and poor prognosis in triple negative breast cancer. Proc Natl Acad Sci U S A 2013; 110: 11091-11096.

145 Sun SH. Roles of P2X7 receptor in glial and neuroblastoma cells: the therapeutic potential of P2X7 receptor antagonists. Mol Neurobiol 2010; 41: 351-355.

146 Stagg J, Divisekera U, McLaughlin N, Sharkey J, Pommey S, Denoyer D et al. Anti-CD73 antibody therapy inhibits breast tumor growth and metastasis. Proc Natl Acad Sci USA 2010; 107: 1547-1552.

147 Eltzschig HK, Kohler D, Eckle T, Kong T, Robson SC, Colgan SP. Central role of Sp1-regulated CD39 in hypoxia/ischemia protection. Blood 2009; 113: 224-232.

148 Hatfield SM, Kjaergaard J, Lukashev D, Schreiber TH, Belikoff B, Abbott R et al. Immunological mechanisms of the antitumor effects of supplemental oxygenation. Sci Transl Med 2015; 7: 277ra30.

149 Sitkovsky MV. T regulatory cells: hypoxia-adenosinergic suppression and re-direction of the immune response. Trends Immunol 2009; 30: 102-108.

150 Hodi FS, O'Day SJ, McDermott DF, Weber RW, Sosman JA, Haanen JB et al. Improved survival with ipilimumab in patients with metastatic melanoma. N Engl J Med 2010; 363: 711-723.

151 Allard B, Pommey S, Smyth MJ, Stagg J. Targeting CD73 enhances the antitumor activity of anti-PD-1 and anti-CTLA-4 mAbs. Clin Cancer Res 2013; 19: 5626-5635.
152 Mittal D, Young A, Stannard K, Yong M, Teng MW, Allard B et al. Antimetastatic effects of blocking PD-1 and the adenosine A2A receptor. Cancer Res 2014; 74 3652-3658.

153 Munn DH, Bronte V. Immune suppressive mechanisms in the tumor microenvironment. Curr Opin Immunol 2015; 39: 1-6.

154 Kumar V. Adenosine as an endogenous immunoregulator in cancer pathogenesis: where to go? Purinergic Signal 2013; 9: 145-165.

155 Ryzhov SV, Pickup MW, Chytil A, Gorska AE, Zhang Q, Owens P et al. Role of TGF-beta signaling in generation of CD39+CD73+ myeloid cells in tumors. J Immunol 2014; 193: 3155-3164.

156 Ryzhov S, Novitskiy SV, Goldstein AE, Biktasova A, Blackburn MR, Biaggioni I et al. Adenosinergic regulation of the expansion and immunosuppressive activity of CD11b+Gr1+ cells. J Immunol 2011; 187: 6120-6129.

157 Cekic C, Day YJ, Sag D, Linden J. Myeloid expression of adenosine A2A receptor suppresses T and NK cell responses in the solid tumor microenvironment. Cancer Res 2014; 74: 7250-7259.

158 lannone R, Miele L, Maiolino P, Pinto A, Morello S. Blockade of A2b adenosine receptor reduces tumor growth and immune suppression mediated by myeloidderived suppressor cells in a mouse model of melanoma. Neoplasia 2013; 15: 1400-1409.

159 Bergamin LS, Braganhol E, Figueiro F, Casali EA, Zanin RF, Sevigny J et al. Involvement of purinergic system in the release of cytokines by macrophages exposed to glioma-conditioned medium. J Cell Biochem 2015; 116: 721-729.

160 Michaud M, Martins I, Sukkurwala AQ, Adjemian S, Ma Y, Pellegatti P et al. Autophagy-dependent anticancer immune responses induced by chemotherapeutic agents in mice. Science 2011; 334: 1573-1577.

161 Casares N, Pequignot MO, Tesniere A, Ghiringhelli F, Roux S, Chaput N et al. Caspase-dependent immunogenicity of doxorubicin-induced tumor cell death. $J$ Exp Med 2005; 202: 1691-1701.

162 Galluzzi L, Buque A, Kepp O, Zitvogel L, Kroemer G. Immunological effects of conventional chemotherapy and targeted anticancer agents. Cancer Cell 2015; 28: $690-714$

163 Kroemer G, Galluzzi L, Kepp O, Zitvogel L. Immunogenic cell death in cancer therapy. Annu Rev Immunol 2013; 31: 51-72.

164 Martins I, Tesniere A, Kepp O, Michaud M, Schlemmer F, Senovilla L et al. Chemotherapy induces ATP release from tumor cells. Cell Cycle 2009; 8: 3723-3728.

165 Ghiringhelli F, Apetoh L, Tesniere A, Aymeric L, Ma Y, Ortiz C et al. Activation of the NLRP3 inflammasome in dendritic cells induces IL-1beta-dependent adaptive immunity against tumors. Nat Med 2009; 15: 1170-1178.

166 Hofman P, Cherfils-Vicini J, Bazin M, llie M, Juhel T, Hebuterne $X$ et al Genetic and pharmacological inactivation of the purinergic P2RX7 receptor dampens inflammation but increases tumor incidence in a mouse model of colitis-associated cancer. Cancer Res 2015; 75: 835-845.

167 Di Virgilio F. P2X receptors and inflammation. Curr Med Chem 2015; 22: 866-877.

168 Shabbir M, Thompson C, Jarmulowiczc M, Mikhailidis D, Burnstock G. Effect of extracellular ATP on the growth of hormone-refractory prostate cancer in vivo. BJU Int 2008; 102: 108-112.

169 Fang J, Chen X, Wang S, Xie T, Du X, Liu H et al. The expression of P2X(7) receptors in EPCS and their potential role in the targeting of EPCS to brain gliomas. Cancer Biol Ther 2015; 16: 498-510.

(c) $\Theta$ This work is licensed under a Creative Commons Attribution(n) other third party material in this article are included in the article's Creative Commons license, unless indicated otherwise in the credit line; if the material is not included under the Creative Commons license, users will need to obtain permission from the license holder to reproduce the material. To view a copy of this license, visit http:// creativecommons.org/licenses/by-nc-nd/4.0/ 